\title{
SIFAT KIMIA DAN FISIK TANAH YANG BERPENGARUH TERHADAP PRODUKSI BAWANG DAUN (Allium fistulosum L) SERTA NILAI EKONOMI LAHAN PADA BERBAGAI KETINGGIAN (Studi Kasus di Wilayah Pacet, Cianjur, Jawa barat)
}

\author{
Heppy Suci Wulanningtyas dan Afrizal Malik \\ Balai Pengkajian Teknologi Pertanian (BPTP) Papua \\ Email: zea_rizal@yahoo.co.id
}

\begin{abstract}
This research aims to (1) identification the effect of soil physical and chemical characteristics to the yield of green onion planted from $800-1.400$ metres above sea level (mdpl), (2) identification of fertilizer and elevation effect, (3) identification of landrent with potential development. The experimental plots were located in Pacet, Cianjur Regency, West Java. This research utilize primary data of soil physical and chemical characteristics that is $\mathrm{pH}, \mathrm{C}$-Organic, Total $\mathrm{N}, \mathrm{P}, \mathrm{Ca}, \mathrm{Mg}$, $K, \mathrm{Na}, \mathrm{KTK}, \mathrm{KB}, \mathrm{Al}, \mathrm{H}, \mathrm{Fe}, \mathrm{Cu}, \mathrm{Zn}, \mathrm{Mn}$, sand, dust and clay texture.By employing Forward Stepwise - Multiple Regression, it was showed that Fe has a positive effect to green onion production at the non fertilized farmland, while $\mathrm{Na}$ and $\mathrm{Al}$ have negative effects. Adversely, at the fertilized farmland, all significant factors have negative effect, a case in point : elevation, Zn element and sand texture. Fertilization has a positive effect to green onion production at all level of elevation. Non fertilized farmland could produce average yield of onion production from $800-1.400 \mathrm{mdpl}$ successively as follows : 13.395,1 kg/ha, 17.263,4 kg/ha, 14.351,9 kg/ha and 15.802,5 $\mathrm{kg} / \mathrm{ha}$. While fertilized farmland could produce average yield of onion production from 800 - $1.400 \mathrm{mdpl}$ successively as follows : $18.172,8 \mathrm{~kg} / \mathrm{ha}, 23.415,6 \mathrm{~kg} / \mathrm{ha}, 20.655,3$ $\mathrm{kg} / \mathrm{ha}$ and 20.853,9 $\mathrm{kg} / \mathrm{ha}$. Fertilization can increase productivity, and the highest productivity was reached at $1.000 \mathrm{mdpl}$. The highest landrent reached at $1.400 \mathrm{mdpl}$. The landrent from $800-1.400 \mathrm{mdpl}$ are $R p .9 .151 / \mathrm{m}^{2}, R p .8 .386 / \mathrm{m}^{2}, R p .7 .337 / \mathrm{m}^{2}$ and Rp. $10.522 / \mathrm{m}^{2}$.
\end{abstract}

Keywords :soil, green onion, elevation, fertilization, landrent

\begin{abstract}
Abstrak: Penelitian bertujuan untuk (1) mengetahui sifat fisik dan kimia tanah yang berpengaruh terhadap produksi bawang daun pada ketinggian 800-1.400 meter dpl (dari permukaan laut), (2) mengetahui pengaruh pemupukan dan ketinggian, dan (3) mengetahui nilai ekonomi lahan pada ketinggian 800-1.400 meter dpl serta potensi pengembangannya.Penelitian dilaksanakan di Kecamatan Pacet, kabupaten Cianjur Jawa Barat. Data dianalisis sifat kimia dan fisik tanah yaitu $\mathrm{pH}, \mathrm{C}$-organik, N Total, $\mathrm{P}, \mathrm{Ca}, \mathrm{Mg}, \mathrm{K}, \mathrm{Na}, \mathrm{KTK}, \mathrm{KB}, \mathrm{Al}, \mathrm{H}, \mathrm{Fe}, \mathrm{Cu}, \mathrm{Zn}, \mathrm{Mn}$, pasir, debu dan liat.Untuk data ekonomi dianalisis secara finansial.Hasil analisis dengan Forward Stepwise-Multiple Regression, menunjukkan faktor yang berpengaruh positif pada produksi bawang daun dengan perlakuan tanpa pemupukan adalah unsur $\mathrm{Fe}$. Sedangkan faktor yang berpengaruh negatif adalah unsur $\mathrm{Na}$ dan $\mathrm{Al}$. Pada lahan yang mendapatkan pemupukan, semua faktor berpengaruh negatif terhadap produksi bawang daun yaitu faktor ketinggian tempat, $\mathrm{Zn}$ dan tekstur pasir. Pemupukan berpengaruh terhadap produksi bawang daun pada semua ketinggian.Dari hasil penelitian tanpa pemupukan produksi pada ketinggian $800 \mathrm{~m} \mathrm{dpl}, 1.000 \mathrm{mdpl}, 1.200 \mathrm{~m}$ dpl dan $1.400 \mathrm{~m} \mathrm{dpl}$ berturut-turut $13.395,1 \mathrm{~kg} / \mathrm{ha}, 17.263,4 \mathrm{~kg} / \mathrm{ha}, 14.351,9 \mathrm{~kg} / \mathrm{ha}$ dan $15.802,5 \mathrm{~kg} / \mathrm{ha}$. Sedangkan dengan pemupukan diperoleh produksi 18.172,8 kg/ha, 23.415,6 kg/ha, $20.655,3 \mathrm{~kg} / \mathrm{ha}$ dan $20.853,9 \mathrm{~kg} / \mathrm{ha}$. Secara umum lahan yang dipupuk memberikan
\end{abstract}


produksi lebih besar daripada lahan yang tidak dipupuk dan produksi tertinggi dicapai pada ketinggian $1.000 \mathrm{~m}$ dpl. Nilai ekonomi lahan tertinggi pada $1.400 \mathrm{~m}$ dpl dan terendah $1.200 \mathrm{~m}$ dpl. Nilai tersebut pada tiap ketinggian berturut-turut $800-1.400 \mathrm{~m}$ dpladalah Rp $9.151 / \mathrm{m}^{2}, \mathrm{Rp} 8.386 / \mathrm{m}^{2}, 7.337 / \mathrm{m}^{2}$ and $10.522 / \mathrm{m}^{2}$.

Kata Kunci :Tanah, bawang daun, ketinggian, pemupukan, nilai ekonomi lahan

\section{PENDAHULUAN}

Kabupaten Cianjur merupakan salah satu sentra pengembangan sayuran di Provinsi Jawa Barat. Kecamatan Pacet berada pada ketinggian 8001.400 meter dari permukaan laut (M DPL). Luas lahan yang ditanami bawang daun di Kecamatan Pacet meliputi1.327 ha dari 3.138 ha total lahan yang ditanami sayuran. Produktivitas bawang daun secara nasional 7.89 ton/ha sedangkan produktivitas eksisting di kawasan Kecamatan Pacet 21,6 ton/ha dengan pemupukan yang belum optimal dan ditanam antara ketinggian $800 \mathrm{~m}$ dpl sampai $1.400 \mathrm{~m}$ dpl(Anonim, 2004 $\left.4^{\mathrm{b}}\right)$.Komoditas bawang daun ini mensuplai kebutuhan di kawasan Jakarta dan Jawa Barat.

Tumbuh kembangnya indutri makanan dan restoran, permintaan akan sayuran, terutama bawang daun terus meningkat. Meningkatnya kebutuhan akan bawang daun akan membawa konsekuensi meningkatnya permintaan. Permintaan bawang daun setiap tahun di kawasan ini cenderung meningkat. Hal terlihat dari semakin luas petani mengusahakan bawang daun, walaupun belum ada data yang menunjukan berapa banyak permintaan akan bawang daun. Untuk itu diperlukan suatu penelitian untuk melihat potensi dan kondisi tanah serta nilai ekonominya dikawasan pengembangan bawang daun, terutama di sentra produksi di Kecamatan Pacet Kabupaten Cianjur.

Ditinjau dari segi produksi, produktivitas sayuran bawang daun di Kecamatan Pacet sudah cukup tinggi dan dukungan potensi pengembangan sayuran ini cukup besar. Dalam rangka usaha pengembangan yang optimal perlu diketahui sifat kimia dan fisik tanah yang berpengaruh terhadap produksi bawang daun disamping faktor lingkungan terutama ketinggian. Sehubungan dengan ituperlu dilakukan penelitian.

Penelitian bertujuan (1) mengetahui sifat fisik dan kimia tanah yang berpengaruh terhadap produksi bawang daun pada ketinggian 800-1.400 m dpl, (2) mengetahui pengaruh pemupukan dan ketinggian terhadap produktivitas bawang daun, dan (3) mengetahui nilai ekonomi lahan pada ketinggian 800-1.400 $\mathrm{m} \mathrm{dpl}$ serta potensi pengembangannya.

\section{METODE PENELITIAN}

Penelitian dilaksanakan di Kecamatan Pacet, Kabupaten CianjurJawa Barat pada bulan Maret-Juli 2004. Bawang daun ditanam secara monokultur pada ketinggian 800, 1.000, 1.200 dan $1.400 \mathrm{~m}$ dpl dengan jenis tanah Andosol Distrik, Regosol Distrik, Kambisol Distrik dan Mediteran Argilik. Untuk setiap ketinggian, terdapat 9 petak bawang daun tanpa pemupukan dan 9 petak bawang daun dengan pemupukan yang ditanam berselang seling.Dari empat ketinggian terdapat 36 petak percobaan bawang daun tanpa pemupukan dan 36 petak bawang daun dengan pemupukan. Luas petak $7,86 \mathrm{~m}^{2}$. Pupuk organik yang digunakan adalah pupuk kandang sebanyak 16 ton/ha yang diberikan dua kali pada saat tanam dan 35 HST (hari setelah tanam). Sedangkan pupuk an organik digunakan ZA, SP-36 dan $\mathrm{KCl}$ masingmasing $440 \mathrm{~kg} / \mathrm{ha}$ dengan dua kali pemberian (30 HST dan 45 HST). Panen dilakukan bulan ketiga setelah penanaman, sesuai dengan umur bawang daun. Semua hasil panen dikonversi kehektar.

Dari masing-masing petak setiap ketinggian dilakukan analisis sifat kimia dan fisik tanah. Sifat kimia yang dianalisis adalah $\mathrm{pH}, \mathrm{C}$-organik, $\mathrm{N}$ total, $\mathrm{P}, \mathrm{Ca}, \mathrm{Mg}, \mathrm{K}, \mathrm{Na}$, $\mathrm{KTK}, \mathrm{KB}, \mathrm{Al}, \mathrm{H}, \mathrm{Fe}, \mathrm{Cu}, \mathrm{Zn}$ dan Mn. Sifat fisik tanah yang dianalisis adalah tekstur pasir, debu dan liat.Analisis sifat fisik tanah dilakukan di Laboratorium Fisika Tanah,analisis sifat kimia tanah dilakukan di Laboratorium Kimia dan Kesuburan Tanah Departemen Tanah Fakultas Pertanian Institut Pertanian Bogor. Data hasil analisis diolah dengan Regresi-Stepwise untuk mengetahui sifat kimia dan fisik tanah yang paling menentukan terhadap produktivitas bawang daun.Dilakukan uji t untuk mengetahui 
perbedaan produktivitasbawang daun pada masing-masing ketinggian dengan perlakuan pemupukan dan tanpa pemupukan.

Untuk melengkapi data di atas dilakukan analisis ekonomi. Data ekonomi dikumpulkan dengan cara mewawancarai lima petani bawang daun secara acak sebagai responden pada setiap ketinggian pengamatan.Dari hasil kuesioner diperoleh nilai ekonomi lahan (landrent). Dilakukan analisis Regresi Berganda untuk mengetahui faktor yang berpengaruh terhadap landrent. Selanjutnya dilakukan uji $\mathrm{t}$ untuk mengetahui beda nyata nilai landrentantar ketinggian.

\section{HASIL DAN PEMBAHASAN}

\section{Sifat Kimia dan Fisik Tanah yang Berpengaruh terhadap Produksi Bawang Daun}

Berdasarkan hasil analisis dengan menggunakan Forward Stepwise - Multiple Regression, faktor yang berpengaruh pada produktivitas bawang daun pada tanah yang tidak dipupuk adalah unsur $\mathrm{Fe}, \mathrm{Na}$ dan $\mathrm{Al}$. Sedangkan pada tanah yang dipupuk faktor yang berpengaruh adalah ketinggian tempat, unsur $\mathrm{Zn}$ dan tekstur pasir (Tabel 1).

Pada lahan yang tidak mendapatkan pemupukan, unsur $\mathrm{Fe}$ berpengaruh positif terhadap produktivitas bawang daun, penambahan satu satuan pupuk $\mathrm{Fe}$ akan meningkatkan produksi sebesar 2676,92 satuan meskipun kadarnya relatif tinggi yaitu 1,28 me/100 gram karena pengaruh unsur Mn. Besi (Fe) dan Mn akan selalu berinteraksi, Fe tidak akan aktif apabila ada Mn yang berlebihan (Sarief, 1986) dan kadar Mn dari hasil analisis pada semua ketinggian rata-rata di atas normal yaitu 4,17 me/100 gram (Leiwakabessy, 1988).

Besi dan mangan berperan dalam sistem enzim dan diperlukan untuk sintesis klorofil (Hardjowigeno, 1985; Sarief, 1986). Molassiotis et al (2006)menyatakan bahwa defisiensi $\mathrm{Fe}$ mengakibatkan penurunan kandungan total klorofil dan laju fotosintesis tanaman. Sedangkan unsur $\mathrm{Na}$ dan $\mathrm{Al}$ berpengaruh negatif, penambahan satu satuan $\mathrm{Na}$ dan $\mathrm{Al}$ akan menurunkan produksi sebesar 3264,05 dan 3048,89 satuan. Penambahan unsur $\mathrm{Na}$ akan mengurangi produktivitas karena kadarnya dalam tanah sudah tinggi (PPT, 1983) yaitu 0,62 me/100 gram, sedangkan unsur Al berpengaruh pada penurunan produktivitas meskipun kadarnya rendah $(0,31 \mathrm{me} / 100$ gram), karena $\mathrm{Al}$ akan meracuni tanaman dan berhubungan dengan kemasaman tanah. Dari hasil analisis $\mathrm{pH}$ tanah adalah masam $(5,46)$, sedangkan tanaman bawang daun cenderung menyukai tanah dengan kemasaman netral yaitu antara 6,5-7,5 (Rubatzky dan Yamaguchi, 1998).

Pada lahan yang mendapatkan pemupukan, variabel ketinggian tempat, unsur $\mathrm{Zn}$ dan tekstur pasir berpengarun negatif terhadap produksi bawang daun. Ketinggian tempat yang tidak sesuai dengan bawang daun akan mengurangiproduktivitas 25,23 satuan. Demikian pula unsur $\mathrm{Zn}$ akan mengurangi produktivitas 1.963,76 satuan karena kadar Zn dari hasil analisis sangat tinggi $(4,11 \mathrm{me} / 100$ gram atau 1.335,8 ppm). Menurut Leiwakabessy (1988) kadar $\mathrm{Zn}>400$ ppm mengakibatkan tanaman keracunan.

Tekstur pasir ikut berpengaruh negatif pada produktivitas bawang daun dan nilainya akan menurunkan produksi bawang daun 350,60 satuan. Tanah yang baik untuk pertumbuhan bawang daun adalah tanah dengan tekstur halus, agak halus atau sedang (PPT, 2003). Tanah bertekstur pasir/kasar mempunyai ruang pori makro lebih banyak sehingga kemampuan menahan air rendah dan kapasitas infiltrasinya tinggi, sebaliknya tanaman bawang daun lebih cocok pada kondisi tanah dengan kelembaban 80 - $90 \%$ (Soepardi, 1983; Arsyad 2000).Baskoro dan Tarigan (2007) menyatakan bahwa tanah Andosol yang

Tabel 1. Persamaan Regresi dan Koefisien Determinasi Faktor yang Mempengaruhi Produksi Bawang Daun

\begin{tabular}{llc}
\hline Keterangan & \multicolumn{1}{c}{ Persamaan } & $\mathrm{R}^{2}$ \\
\hline Tanpa Pemupukan & $\mathrm{Y}=25715,25+2676,92 \mathrm{Fe}-3264,05 \mathrm{Na}-3048,89 \mathrm{Al}$ & 0,63 \\
Dengan Pemupukan & $\mathrm{Y}=39425,43-25,23$ ketinggian $-1963,76 \mathrm{Zn}-350,60$ pasir & 0,75 \\
\hline
\end{tabular}


mengandung bahan organik memiliki kelembaban dan kemampuan menahan air paling tinggi sedangkan tanah Regosol yang bertekstur pasir memiliki kelembaban dan kemampuan menahan air paling rendah.

Unsur N, P dan K pada perlakuan tanpa pemupukan dan dengan pemupukan tidak muncul dalam persamaan hasil analisis dan bukan berarti unsur tersebut tidak menentukan dalam produktivitas bawang daun. Kandungan $\mathrm{N}$ total secara umum untuk semua ketinggian berdasarkan kriteria PPT (1983) adalah sedang, yaitu $0,47 \%, 0,45 \%, 0,38 \%$ dan $0,27 \%$. Kadar P dari pada ketinggian $1.400 \mathrm{~m} \mathrm{dpl}$, $1.200 \mathrm{~m}$ dpl dan $1.000 \mathrm{~m}$ dpl sangat rendah yaitu 1,33 ppm, 2,46 ppm dan 4,84 ppm. Kadar $\mathrm{K}$ dalam tanah sedang pada ketinggian $1.400 \mathrm{~m}$ dpl dan $1.000 \mathrm{~m}$ dpl yaitu $0,53 \mathrm{me} / 100$ gram dan $0,55 \mathrm{me} / 100$ gram.Dari hasil analisis secara umum komoditasbawang daun masih memerlukan unsur $\mathrm{N}, \mathrm{P}$ dan $\mathrm{K}$ untuk pertumbuhan vegetatifnya.

Tabel 2. Nilai Rataan Sifat Kimia dan Fisik Tanah pada Empat Ketinggian Tanpa Pemupukan

\begin{tabular}{|c|c|c|c|c|c|}
\hline \multirow{2}{*}{ Keterangan } & \multicolumn{4}{|c|}{ Tanpa Dipupuk } & \multirow{2}{*}{ Rataan } \\
\hline & $1.400 \mathrm{mdpl}$ & $1.200 \mathrm{mdpl}$ & $1.000 \mathrm{mdpl}$ & $800 \mathrm{mdpl}$ & \\
\hline $\mathrm{pH} \mathrm{H}_{2} \mathrm{O}(1: 1)$ & 5,7 & 6 & 5,49 & 4,66 & 5,46 \\
\hline $\begin{array}{l}\text { C-org (\%) } \\
\text { (Walkley and Black) }\end{array}$ & 4,63 & 4,45 & 4,18 & 2,76 & 4,005 \\
\hline $\begin{array}{l}\text { N Total }(\%) \\
\text { (Kjeldhal) }\end{array}$ & 0,45 & 0,44 & 0,37 & 0,25 & 0,38 \\
\hline P Bray 1 (ppm) & 1,72 & 1,7 & 2,94 & 40,56 & 11,73 \\
\hline $\begin{array}{l}\mathrm{Ca}(\mathrm{me} / 100 \mathrm{gr}) \\
\left(\mathrm{N} \mathrm{NH}_{4} \mathrm{OAC} \mathrm{pH} 7,0\right)\end{array}$ & 10,93 & 5,8 & 3,82 & 5,92 & 6,62 \\
\hline $\begin{array}{l}\mathrm{Mg}(\mathrm{me} / 100 \mathrm{gr}) \\
\left(\mathrm{N} \mathrm{NH}_{4} \mathrm{OAC} \mathrm{pH} 7,0\right)\end{array}$ & 1,51 & 1,11 & 0,59 & 0,87 & 1,02 \\
\hline $\begin{array}{l}\mathrm{K}\left(\mathrm{me}_{1} / 00 \mathrm{gr}\right) \\
\left(\mathrm{N} \mathrm{NH}_{4} \mathrm{OAC} \mathrm{pH} 7,0\right)\end{array}$ & 0,39 & 0,40 & 0,32 & 1,39 & 0,63 \\
\hline $\begin{array}{l}\mathrm{Na}(\mathrm{me} / 100 \mathrm{gr}) \\
\left(\mathrm{N} \mathrm{NH}_{4} \mathrm{OAC} \mathrm{pH} \mathrm{7,0)}\right.\end{array}$ & 0,76 & 0,48 & 0,54 & 0,70 & 0,62 \\
\hline $\begin{array}{l}\mathrm{KTK}(\mathrm{me} / 100 \mathrm{gr}) \\
\left(\mathrm{N} \mathrm{NH}_{4} \mathrm{OAC} \mathrm{pH} 7,0\right)\end{array}$ & 29,69 & 28,93 & 29 & 29,17 & 29,2 \\
\hline $\mathrm{KB}(\%)$ & 46,19 & 26,93 & 18,22 & 30,67 & 30,5 \\
\hline $\begin{array}{l}\mathrm{Al}(\mathrm{me} / 100 \mathrm{gr}) \\
(\mathrm{N} \mathrm{KCl})\end{array}$ & 0 & 0 & 0,03 & 1,23 & 0,315 \\
\hline $\begin{array}{l}\mathrm{H}(\mathrm{me} / 100 \mathrm{gr}) \\
(\mathrm{N} \mathrm{KCl})\end{array}$ & 0,23 & 0,20 & 0,23 & 0,27 & 0,23 \\
\hline $\begin{array}{l}\mathrm{Fe}(\mathrm{me} / 100 \mathrm{gr}) \\
(0,05 \mathrm{~N} \mathrm{HCl})\end{array}$ & 1,55 & 1,09 & 1,68 & 0,81 & 1,28 \\
\hline $\begin{array}{l}\mathrm{Cu}(\mathrm{me} / 100 \mathrm{gr}) \\
(0,05 \mathrm{~N} \mathrm{HCl})\end{array}$ & 0,35 & 1,56 & 0,88 & 0,74 & 0,88 \\
\hline $\begin{array}{l}\mathrm{Zn}(\mathrm{me} / 100 \mathrm{gr}) \\
(0,05 \mathrm{~N} \mathrm{HCl})\end{array}$ & 2,23 & 4,29 & 2,88 & 6,40 & 3,95 \\
\hline $\begin{array}{l}\mathrm{Mn}(\mathrm{me} / 100 \mathrm{gr}) \\
(0,05 \mathrm{~N} \mathrm{HCl})\end{array}$ & 2,82 & 2,64 & 3,36 & 7,84 & 4,17 \\
\hline Pasir (\%) & 31,55 & 33,68 & 35,97 & 23,48 & 31,17 \\
\hline Debu (\%) & 48,38 & 44,35 & 47,25 & 49,28 & 47,32 \\
\hline Liat (\%) & 20,07 & 21,96 & 16,79 & 27,24 & 21,52 \\
\hline
\end{tabular}


Heppy Suci W. dan Afrizal Malik: Sifat Kimia Dan Fisik Tanah ...

Tabel 3. Nilai Rataan Sifat Kimia dan Fisik Tanah pada Empat Ketinggian Dengan Pemupukan

\begin{tabular}{|c|c|c|c|c|c|}
\hline \multirow{2}{*}{ Keterangan } & \multicolumn{4}{|c|}{ Dengan Pemupukan } & \multirow{2}{*}{ Rataan } \\
\hline & $1.400 \mathrm{mdpl}$ & $1.200 \mathrm{mdpl}$ & 1. $000 \mathrm{mdpl}$ & $800 \mathrm{mdpl}$ & \\
\hline $\mathrm{pH} \mathrm{H} \mathrm{H}_{2} \mathrm{O}(1: 1)$ & 5,65 & 5,75 & 4,94 & 4,26 & 5,15 \\
\hline $\begin{array}{l}\text { C-org }(\%) \\
\text { (Walkley and Black) }\end{array}$ & 5,02 & 4,72 & 4,08 & 2,93 & 4,19 \\
\hline $\begin{array}{l}\text { N Total }(\%) \\
\text { (Kjeldhal) }\end{array}$ & 0,49 & 0,45 & 0,39 & 0,29 & 0,405 \\
\hline P Bray 1 (ppm) & 0,94 & 3,22 & 6,74 & 52,52 & 15,86 \\
\hline $\begin{array}{l}\mathrm{Ca}(\mathrm{me} / 100 \mathrm{gr}) \\
\left(\mathrm{N} \mathrm{NH}_{4} \mathrm{OAC} \mathrm{pH} 7,0\right)\end{array}$ & 10,71 & 6,63 & 5,95 & 6,15 & 7,36 \\
\hline $\begin{array}{l}\mathrm{Mg}(\mathrm{me} / 100 \mathrm{gr}) \\
\left(\mathrm{N} \mathrm{NH}_{4} \mathrm{OAC} \mathrm{pH} 7,0\right)\end{array}$ & 1,61 & 1,41 & 1 & 0,93 & 1,24 \\
\hline $\begin{array}{l}\mathrm{K}(\mathrm{me} / 100 \mathrm{gr}) \\
\left(\mathrm{N} \mathrm{NH}_{4} \mathrm{OAC} \mathrm{pH} 7,0\right)\end{array}$ & 0,68 & 0,94 & 0,77 & 1,47 & 0,97 \\
\hline $\begin{array}{l}\mathrm{Na}(\mathrm{me} / 100 \mathrm{gr}) \\
\left(\mathrm{N} \mathrm{NH}_{4} \mathrm{OAC} \mathrm{pH} 7,0\right)\end{array}$ & 1,04 & 0,80 & 0,70 & 1,24 & 0,95 \\
\hline $\begin{array}{l}\mathrm{KTK}(\mathrm{me} / 100 \mathrm{gr}) \\
\left(\mathrm{N} \mathrm{NH}_{4} \mathrm{OAC} \mathrm{pH} 7,0\right)\end{array}$ & 28,52 & 31,55 & 30,06 & 29,69 & 29,96 \\
\hline $\mathrm{KB}(\%)$ & 49,56 & 30,99 & 28,16 & 32,97 & 35,42 \\
\hline $\begin{array}{l}\mathrm{Al}(\mathrm{me} / 100 \mathrm{gr}) \\
(\mathrm{N} \mathrm{KCl})\end{array}$ & 0 & 0 & 0,16 & 1,88 & 0,51 \\
\hline $\begin{array}{l}\mathrm{H}(\mathrm{me} / 100 \mathrm{gr}) \\
(\mathrm{N} \mathrm{KCl})\end{array}$ & 0,24 & 0,23 & 0,22 & 0,31 & 0,25 \\
\hline $\begin{array}{l}\mathrm{Fe}(\mathrm{me} / 100 \mathrm{gr}) \\
(0,05 \mathrm{~N} \mathrm{HCl})\end{array}$ & 1,29 & 1,44 & 0,89 & 1 & 1,16 \\
\hline $\begin{array}{l}\mathrm{Cu}(\mathrm{me} / 100 \mathrm{gr}) \\
(0,05 \mathrm{~N} \mathrm{HCl})\end{array}$ & 0,54 & 0,62 & 1,20 & 0,52 & 0,72 \\
\hline $\begin{array}{l}\mathrm{Zn}(\mathrm{me} / 100 \mathrm{gr}) \\
(0,05 \mathrm{~N} \mathrm{HCl})\end{array}$ & 2,66 & 4,06 & 3,22 & 6,5 & 4,11 \\
\hline $\begin{array}{l}\mathrm{Mn}(\mathrm{me} / 100 \mathrm{gr}) \\
(0,05 \mathrm{~N} \mathrm{HCl})\end{array}$ & 3,44 & 3,76 & 6,42 & 23,46 & 9,27 \\
\hline Pasir (\%) & 30,46 & 37,29 & 37,34 & 21,86 & 31,74 \\
\hline Debu (\%) & 43,64 & 51,48 & 45,16 & 40,68 & 45,24 \\
\hline Liat (\%) & 25,89 & 11,23 & 17,50 & 37,46 & 23,02 \\
\hline
\end{tabular}

2. Hubungan Produksi dengan Ketinggian serta Pengaruh Pemupukan terhadap Produksi Bawang Daun

Pada lahan yang tidak mendapatkan pemupukan, produksi tertinggi pada ketinggian $1.000 \mathrm{~m}$ dpl yaitu 17.263,4 $\mathrm{kg} / \mathrm{ha}$ dan produktivitas terendah ketinggian $800 \mathrm{mdpl}$ $13.395,1 \mathrm{~kg} / \mathrm{ha}$. Produksi secara berturut-turut dari ketinggian $800-1.400 \mathrm{~m}$ dpl adalah $13.395,1 \mathrm{~kg} / \mathrm{ha}, 17.263,4 \mathrm{~kg} / \mathrm{ha}, 14.351,9 \mathrm{~kg} / \mathrm{ha}$ dan $15.802,5 \mathrm{~kg} / \mathrm{ha}$.Demikian pula pada lahan yang mendapatkan pemupukan unsur $\mathrm{N}, \mathrm{P}$ dan $\mathrm{K}$, produktivitas tertinggi pada ketinggian $1.000 \mathrm{~m}$ dpl yaitu 23.415,6 kg/ha dan produktivitas terendah pada ketinggian $800 \mathrm{~m}$ dpl yaitu $18.172,8 \mathrm{~kg} / \mathrm{ha}$. Produksi secara berturut-turut dari ketinggian $800-1.400 \mathrm{~m}$ dpl adalah $18.172,8 \mathrm{~kg} / \mathrm{ha}, 23.415,6 \mathrm{~kg} / \mathrm{ha}$, $20.655,3 \mathrm{~kg} / \mathrm{ha}$ dan $20.853,9 \mathrm{~kg} / \mathrm{ha}$. Pemberian bahan organik dan pemupukan $\mathrm{N}, \mathrm{P}, \mathrm{K}$ akan meningkatkan serapan hara dan hasil suatu komoditas pada tanah inceptisol (Rahman, et.al, 2008). Tanah inceptisol adalah nama laindari tanah Kambisol dan Mediteran.

Ketinggian tempat, khususnya pada lahan yang mendapat pemupukan, berpengaruh pada produktivitas. Hal ini karena ada hubungan antara ketinggian dengan iklim (suhu) dan intensitas cahaya matahari. Meskipun data pengamatan lapang pada empat 
Tabel 4. Hasil Uji t pada Lahan dengan Perlakuan Pemupukan dan Tanpa Pemupukan pada Empat Titik Ketinggian

\begin{tabular}{|c|c|c|}
\hline Perbandingan Perlakuan dan Ketinggian & Nilai t & $\mathrm{p}$ \\
\hline P0 $1.400 \mathrm{~m}$ dpl dengan P0 $1.200 \mathrm{~m}$ dpl & 2,12 & $0,05000 *$ \\
\hline P0 $1.400 \mathrm{~m}$ dpl dengan P0 $1.000 \mathrm{~m}$ dpl & $-1,58$ & 0,13400 \\
\hline P0 $1.400 \mathrm{~m}$ dpl dengan P0 $800 \mathrm{~m}$ dpl & 2,77 & $0,01400^{*}$ \\
\hline P0 $1.200 \mathrm{~m}$ dpl dengan P0 $1.000 \mathrm{~m}$ dpl & $-2,88$ & $0,01100 *$ \\
\hline P0 $1.200 \mathrm{~m}$ dpl dengan P0 $800 \mathrm{~m}$ dpl & 0,99 & 0,33300 \\
\hline P0 $1.000 \mathrm{~m}$ dpl dengan P0 $800 \mathrm{~m} \mathrm{dpl}$ & 3,38 & $0,00400^{*}$ \\
\hline P1 1.400 m dpl dengan P1 $1.200 \mathrm{~m}$ dpl & 0,18 & 0,86300 \\
\hline P1 $1.400 \mathrm{~m}$ dpl dengan P1 $1.000 \mathrm{~m}$ dpl & $-1,99$ & 0,06400 \\
\hline P1 $1.400 \mathrm{~m}$ dpl dengan P1 $800 \mathrm{~m}$ dpl & 1,83 & 0,08500 \\
\hline P1 $1.200 \mathrm{~m}$ dpl dengan P1 $1.000 \mathrm{~m}$ dpl & $-2,06$ & 0,05600 \\
\hline P1 $1.200 \mathrm{~m}$ dpl dengan P1 $800 \mathrm{~m}$ dpl & 1,64 & 0,12000 \\
\hline P1 $1.000 \mathrm{~m}$ dpl dengan P1 $800 \mathrm{~m}$ dpl & 3,21 & $0,00500^{*}$ \\
\hline P0 1.400 m dpl dengan P1 $1.400 \mathrm{~m}$ dpl & $-5,96$ & $0,00002 *$ \\
\hline P0 $1.200 \mathrm{~m}$ dpl dengan P1 $1.200 \mathrm{~m}$ dpl & $-6,22$ & $0,00001 *$ \\
\hline P0 $1.000 \mathrm{~m}$ dpl dengan P1 $1.000 \mathrm{~m}$ dpl & $-4,59$ & $0,00030 *$ \\
\hline P0 800 m dpl dengan P1 800 m dpl & $-3,24$ & $0,00500 *$ \\
\hline
\end{tabular}

Keterangan : *, berbeda nyata pada $\alpha=0,05$

P0 : tidak dipupuk

$\mathrm{P} 1$ : dipupuk

ketinggian suhu semua lokasi termasuk kelas S1 yaitu berada pada kisaran suhu $17.9^{\circ} \mathrm{C}$ sampai $21.5^{\circ} \mathrm{C}$, tetapi pada ketinggian $1.000 \mathrm{~m}$ $\mathrm{dpl}$, suhu dan intensitas cahaya matahari paling kondusif untuk pertumbuhan bawang daun.

Dari hasil uji t, perlakuan pemupukan pada semua ketinggian memberikan hasil berbeda nyata dengan lahan yang tidak mendapatkan pemupukan. Secara ringkas, hasil uji t disampaikan pada Tabel 4.

\section{Nilai Ekonomi Lahan (Landrent) Usahatani Bawang Daun}

Menghitung nilai landrent, komponen input dan output usahatani yang dimasukkan yaitu biaya bibit bawang daun, pupuk, pestisida, tenaga kerja, pajak/sewa lahan, biaya penyusutan alat dan hasil produksi. Biaya transportasi untuk pengadaan bibit dan pupuk serta pengangkutan hasil panen dimasukkan dalam biaya tenaga kerja pria. Diketahui bahwa nilai landrent paling tinggi pada ketinggian $1.400 \mathrm{~m}$ dpl dan paling rendah pada ketinggian $1.200 \mathrm{~m}$ dpl (Tabel 5). Dengan demikian usahatani bawang daun paling menguntungkan jika ditanam pada ketinggian $1.400 \mathrm{~m}$ dpl. empat ketinggian menunjukkan nilai yang berbeda-beda (Tabel 6). Hasil uji beda nyata nilai landrent pada empat ketinggian menunjukkan nilai yang berbeda-beda (Tabel $6)$. 
Heppy Suci W. dan Afrizal Malik: Sifat Kimia Dan Fisik Tanah ...

Tabel 5. Nilai Landrent Setiap Ketinggian

\begin{tabular}{ccc}
\hline Ketinggian & Produksi Rata-Rata & ${\text { Landrent } / \mathrm{m}^{2}}^{2}$ \\
\hline $800 \mathrm{~m} \mathrm{dpl}$ & $19,071 \mathrm{~kg} / \mathrm{ha} / \mathrm{th}$ & $\mathrm{Rp} \mathrm{9,151}$ \\
$1.000 \mathrm{~m} \mathrm{dpl}$ & $18,737 \mathrm{~kg} / \mathrm{ha} / \mathrm{th}$ & $\mathrm{Rp} 8,386$ \\
$1.200 \mathrm{~m} \mathrm{dpl}$ & $17,738 \mathrm{~kg} / \mathrm{ha} / \mathrm{th}$ & $\mathrm{Rp} \mathrm{7,337}$ \\
$1.400 \mathrm{~m} \mathrm{dpl}$ & $20,986 \mathrm{~kg} / \mathrm{ha} / \mathrm{th}$ & $\mathrm{Rp} \mathrm{10,522}$ \\
\hline
\end{tabular}

Tabel 6. Hasil Uji t Nilai Landrent pada Empat Ketinggian

\begin{tabular}{lcc}
\hline Perbandingan Ketinggian & Nilai t & $\mathrm{p}$ \\
\hline $1.400 \mathrm{~m}$ dpl dengan $1.200 \mathrm{~m} \mathrm{dpl}$ & 7,892 & $\mathbf{0 , 0 0 0}$ \\
$1.400 \mathrm{~m}$ dpl dengan $1.000 \mathrm{~m} \mathrm{dpl}$ & 2,617 & $\mathbf{0 , 0 4 9 *}$ \\
$1.400 \mathrm{~m}$ dpl dengan $800 \mathrm{~m} \mathrm{dpl}$ & 2,225 & 0,057 \\
$1.200 \mathrm{~m}$ dpl dengan $1.000 \mathrm{~m} \mathrm{dpl}$ & $-1,257$ & 0,262 \\
$1.200 \mathrm{~m}$ dpl dengan $800 \mathrm{~m} \mathrm{dpl}$ & $-2,829$ & $\mathbf{0 , 0 2 2}$ \\
$1.000 \mathrm{~m}$ dpl dengan $800 \mathrm{~m} \mathrm{dpl}$ & $-0,799$ & 0,447 \\
\hline
\end{tabular}

Keterangan : *, berbeda nyata pada $\alpha=0,05$

\section{Faktor yang Mempengaruhi Landrent}

Faktor utama yang berpengaruh terhadap landrent adalah jumlah produktivitas, biaya bibit, biaya pupuk kandang dan biaya pupuk SP-36. Faktor ketinggian berpegaruh terhadap landrent dan produksi bawang daun tetapi dengan nilai yang lebih kecil dibandingkan dengan faktor lain. Hasil analisis regresi peubah baru terhadap peubah tujuan nilai landrent dapat dilihat dalam Tabel 7 . Perbedaan produksi pada setiap ketinggian berpengaruh positif terhadap nilai landrent. Rata-rata produktivitas tertinggi dicapai pada ketinggian $1.400 \quad \mathrm{~m} \quad$ dpl yaitu 20,986 $\mathrm{kg} / \mathrm{ha} / \mathrm{tahun}$ dan rata-rata produksi terendah dicapai pada ketinggian $1.200 \mathrm{~m}$ dpl yaitu $17,738 \mathrm{~kg} / \mathrm{ha} /$ tahun.Faktor utama yang berpengaruh terhadap produksi bawang daun adalah variabel bibit (Tabel 8).

Biaya bibit berbanding lurus dengan jumlah bibit. Apabila biaya bibit besar maka jumlah bibit yang dibeli dan digunakan petani juga semakin besar. Semakin banyak bibit yang digunakan maka akan semakin banyak hasil panen petani dan produktivitas yang diperoleh akan meningkat sehingga akan meningkatkan nilai landrent. Dengan demikian biaya bibit berpengaruh positif terhadap produksi bawang daun dan landrent.Penambahan satu-satuan bibitakan meningkatkan produktivitas sebesar 1.514 satuan. Penggunaan bibit oleh petani terbanyak pada ketinggian $1400 \mathrm{~m} \mathrm{dpl}$, selanjutnya pada ketinggian $1.200 \mathrm{~m}$ dpl, 1.000 $\mathrm{m}$ dpl dan $800 \mathrm{~m}$ dpl. Rata-rata penggunaan bibit untuk satu kali tanam pada masingmasing ketinggian adalah $5,718 \mathrm{~kg} / \mathrm{ha}, 5,405$ $\mathrm{kg} / \mathrm{ha}, 5,380 \mathrm{~kg} / \mathrm{ha}$ dan $5,148 \mathrm{~kg} / \mathrm{ha}$.

Pupuk kandang berpengaruh negatif terhadap landrent. Peningkatan satu satuan harga pupuk kandang akan menurunkan nilai landrent sebesar 8.764 satuan. Hal ini disebabkan karena penggunaan pupuk kandang di lapangan sudah terlalu banyak sehingga biaya yang dikeluarkan untuk membeli pupuk kandang akan mengurangi pendapatan petani. Rata-rata pemakaian pupuk kandang untuk satu kali tanam dari ketinggian $800 \mathrm{~m}$ dpl sampai 1.400 $\mathrm{m}$ dpl secara berturut-turut adalah 6,50 ton/ha, 7,10 ton/ha, 6,65 ton/ha dan 7,40 ton/ha. Sedangkan standar dari Dinas Pertanian Cianjur, pemakaian pupuk kandang (pupuk organik) untuk bawang daun adalah 5.29 ton/ha. 
Heppy Suci W. dan Afrizal Malik: Sifat Kimia Dan Fisik Tanah ...

Tabel 7. Hasil Analisis Regresi Berganda Terhadap Peubah Nilai Landrent

\begin{tabular}{lcc}
\hline Faktor Utama & Koefisien Regresi (B) & Nilai p \\
\hline Jumlah Produksi Bawang Daun & 0,000 & $\mathbf{0 , 0 0 0 *}$ \\
Biaya Bibit & 0,000 & $\mathbf{0 , 0 0 0 *}$ \\
Biaya Pupuk Kandang & $-8,764 \times 10^{-5}$ & $\mathbf{0 , 0 0 0 *}$ \\
Biaya Pupuk SP-36 & 0,000 & $\mathbf{0 , 0 0 8}$ \\
\hline
\end{tabular}

Keterangan : Nilai $\mathrm{R}^{2}=0,98$ dan tanda $*$ berarti berpengaruh nyata pada $\alpha=0,05$

Tabel 8. Hasil Analisis Regresi Berganda Terhadap Peubah Nilai Produksi

\begin{tabular}{lcc}
\hline Faktor Utama & Koefisien Regresi $(\mathrm{B})$ & Nilai p \\
\hline Intercept & $1,124 \times 10^{8}$ & $\mathbf{0 , 0 0 2 *}$ \\
Biaya Bibit & 1,514 & $\mathbf{0 , 0 0 2 *}$ \\
\hline
\end{tabular}

Keterangan : Nilai $\mathrm{R}^{2}=0,38$ dan tanda $*$ berarti berpengaruh nyata pada $\alpha=0,05$

Sebaliknya, pupuk SP-36 berpengaruh positif terhadap landrent.Pemakaian SP-36 di lapangan belum sesuai dan belum memenuhi kebutuhan sayuran bawang daun. Standar dari Dinas Pertanian Cianjur menyebutkan bahwa pemakaian SP-36 untuk bawang daun untuk satu kali tanam adalah $350 \mathrm{~kg} / \mathrm{ha}$, sedangkan rata-rata penggunaan SP-36 di lapangan adalah $343 \mathrm{~kg} / \mathrm{ha}$. Rata-rata pemakaian pupuk SP-36 untuk satu kali tanam dari ketinggian $800 \mathrm{~m}$ dpl sampai $1.400 \mathrm{~m}$ dpl secara berturut-turut adalah $420 \mathrm{~kg} / \mathrm{ha}, 358 \mathrm{~kg} / \mathrm{ha}, 300 \mathrm{~kg} / \mathrm{ha}$ dan $295 \mathrm{~kg} / \mathrm{ha}$. Dari hasil analisis di laboratorium juga menunjukkan bahwa kadar P dalam tanah pada ketinggian $1.000 \mathrm{~m} \mathrm{dpl}, 1.200 \mathrm{~m} \mathrm{dpl}, 1.400 \mathrm{~m}$ dpl adalah sangat rendah dan hanya pada ketinggian $800 \mathrm{~m}$ dpl kadar P tinggi. Dengan demikian tanah masih memerlukan pupuk SP36 untuk meningkatkan produksi. Apabila produksi bawang daun meningkat maka nilai landrentakan meningkat pula.

\section{KESIMPULAN DAN SARAN}

1. Faktor yang berpengaruh pada produksi bawang daun tanpa pemupukan adalah unsur $\mathrm{Fe}, \mathrm{Na}$ dan $\mathrm{Al}$, sedangkan dengan pemupukan yang berpengaruh adalah ketinggian tempat, $\mathrm{Zn}$ dan tekstur pasir.
2. Berdasarkan hasil penelitian, lahan yang dipupuk memberikan produktivitas lebih tinggi daripada lahan yang tidak dipupuk dan produktivitas tertinggi dicapai pada ketinggian $1.000 \mathrm{~m}$ dpl.

3. Nilai landrent tertinggi pada ketinggian $1.400 \mathrm{~m}$ dpl dan terendah pada ketinggian $1.200 \mathrm{~m}$ dpl.Faktor yang berpengaruh terhadap landrent adalah jumlah produksi bawang daun, biaya bibit, biaya pupuk kandang dan biaya pupuk SP-36.

4. Berdasarkan hasil penelitian, wilayah yang paling berpotensi untuk pengembangan sayuran bawang daun berada pada ketinggian $1.000 \mathrm{~m} \mathrm{dpl}$. Sebaliknya berdasarkan hasil analisis landrent, wilayah yang paling berpotensi untuk pengembangan bawang daun berada pada ketinggian $1.400 \mathrm{~m}$ dpl. Akan tetapi pemilihan lokasi untuk suatu usahatani disarankan berdasarkan data hasil penelitian yaitu pada ketinggian $1.000 \mathrm{~m}$ dpl karena data hasil percobaan ini reliabilitasnya lebih tinggi sebab mendapat perlakuan yang homogen dan ada kontrol yang jelas. 


\section{DAFTAR PUSTAKA}

Anonim. 2004 a . Bawang Daun (Allium sp). http://warintek.progressio.or.id/pertanian /bdaun.htm.

Anonim.2004 $4^{\mathrm{b}}$.TanamanPangan.http://www.ka wasan.or.id/kliping/tanamanpangan/tp26 0304_0002.htm

Anonim. 1997. Kriteria Kesesuaian Tanah dan Iklim Tanaman Pertanian. Departemen Pertanian. Jakarta.

Anonim.2014. Budidaya Bawang Daun. http://www.hortikultura.litbang.pertanian .go.id.

Anonim.2014. Harga Sayuran 19-09-2014. http://www.bpbtphpacet.com.

Arsyad, S. 2000. Konservasi Tanah dan Air. IPB Press. Bogor.

Baskoro, D.P.T., and S.D. Tarigan. 2007. Soil Moisture Characteristics on Several Soil Types. Jurnal of Soil and Environment, DITSL-Faperta IPB.Vol 9 No 2.

Djaenudin,D., M. Hendrisman, H. Subagjo dan A. Hidayat. 2003. Petunjuk Teknis Evaluasi Lahan untuk Komoditas Pertanian. Pusat Penelitian dan Pengembangan Tanah dan Agroklimat. Departemen Pertanian. Bogor.

Hardjowigeno, S. 1985. Klasifikasi TanahSurvey Tanah dan Evaluasi Kemampuan Lahan. Jurusan Tanah. Fakultas Pertanian. IPB. Bogor.

Leiwakabessy, F.M. 1988. Bahan Kuliah Kesuburan Tanah. Jurusan Tanah. Fakultas Pertanian. IPB. Bogor.

Leiwakabessy, F.M dan A. Sutandi. 1998. Pupuk dan Pemupukan. Jurusan Tanah. Fakultas Pertanian. IPB. Bogor.

Molassiatis, A., G. Tanou, G. Diamantidis, A. Patakas and I. Therios. 2006. Effects of 4-Month Fe Deficiency Exposure on Fe Reduction Mechanism, Photosynthetic
Gas Exchange, Clorophyll Fluorescence and Antioxidant Defense in Two Peachrootstocks Differing in $\mathrm{Fe}$ Deficiency Tolerance. Journal of Plant Physiology.Volume 163 : 176-185.

Pusat Penelitian Tanah dan Agroklimat. 1978. Laporan Survey dan Pemetaan Tanah Daerah Aliran Sungai Citarum III Padalarang-Jawa Barat. Pusat Penelitian Tanah dan Agroklimat. Bogor.

Pusat Penelitian Tanah dan Agroklimat. 1983. Kriteria Penilaian Sifat-Sifat Kimia Tanah. Pusat Penelitian Tanah dan Agroklimat. Bogor.

Pusat Penelitian Tanah dan Agroklimat. 2003. Petunjuk Teknis Evaluasi Lahan untuk Komoditas Pertanian. Pusat Penelitian Tanah dan Agroklimat. Bogor.

Rachman, I.A., S. Djuniwati and K. Idris. 2008. The Effects of Organic Matter and N, P, $\mathrm{K}$ Fertilizer on Nutrient Uptake and Yield of Corn in Inceptisol Ternate. Jurnal of Soil and Environment, DITSLFaperta IPB.Vol 10 No 1.

Rahardi, F., R. Palungkun dan A. Budiarti. 1993. Agribisnis Tanaman Sayur. Penebar Swadaya. Jakarta.

Rubatzky, V.E dan M. Yamaguchi. 1998. Sayuran Dunia 2: Prinsip, Produksi dan Gizi. Edisi 2. ITB Bandung. Bandung.

Sarief, E. Saifuddin. 1986. Kesuburan dan Pemupukan Tanah Pertanian. Pustaka Buana. Bandung.

Sidik, P. 2002. Evaluasi Kesesuaian Lahan Fisik dan Analisis Kelayakan Finansial Empat Pola Tanam Sayuran pada Satuan Peta Tanah Andosol, Regosol dan Mediteran (Studi Kasus Kecamatan Pacet, Kabupaten Cianjur, Jawa Barat). Skripsi. Departemen Tanah. Fakultas Pertanian. IPB Bogor.

Soepardi, G. 1983. Sifat dan Ciri Tanah. Jurusan Tanah. Fakultas Pertanian. IPB. Bogor. 
Heppy Suci W. dan Afrizal Malik: Sifat Kimia Dan Fisik Tanah ...

Sumiyati. 2006. Analisis Pendapatan dan Efisiensi Penggunaan Faktor-Faktor Produksi Usahatani Bawang Daun. Skripsi. Program Studi Manajemen Agribisnis. Fakultas Pertanian. IPB. Bogor.
Wiranegara, H dan Suwardi. 2000. Penuntun Praktikum Morfologi dan Klasifikasi Tanah. Jurusan Tanah. Fakultas Pertanian. IPB. Bogor. 